\title{
TOKSISITAS EKSTRAK BIJI PINANG (Areca catechu L.) TERHADAP ULAT KROP KUBIS (Crocidolomia pavonana F.) DI LABORATORIUM
}

\author{
Kalbi Rikardo, Solikhin \& Nur Yasin \\ Jurusan Agroteknologi, Fakultas Pertanian, Universitas Lampung \\ J1. Prof. Soemantri Brojonegoro, No. 1 Bandar Lampung 35145 \\ Email: kalbirikardo.klwpart@gmail.com
}

\begin{abstract}
ABSTRAK
Ulat krop kubis (Crocidolomia pavonana F.) merupakan salah satu jenis hama yang menimbulkan masalah pada pertanian kubis. Penggunaan insektisida kimia dengan konsentrasi tinggi serta interval penyemprotan yang sering dapat menyebabkan efek residu pestisida. Salah satu tanaman yang berpotensi sebagai pestisida nabati untuk mengendalikan hama adalah tanaman pinang. Bagian dari tanaman pinag yang paling banyak digunakan sebagai insektisida nabati yaitu biji pinang muda (Areca catechu L.). Tujuan dari penelitian ini untuk mengetahui toksisitas ekstrak biji pinang (Areca catechu L.) terhadap mortalitas ulat krop kubis (Crocidolomia pavonana. Konsentrasi larutan ekstrak biji buah pinang yang digunakan sebagai konsentrasi uji toksisitas lanjutan adalah $30 \%, 20 \%, 10 \%, 5 \%, 1 \%, 0.8 \%, 0.6 \%, 0.4 \%, 0.2$ dan $0 \%$. Data dari uji daya racun dianalisis dengan analisis probit menggunakan Software SPSS version 23 for windows. Nilai toksisitas LC $\mathrm{L}_{50} \mathrm{ekstrak}_{\mathrm{biji}}$ buah pinang ditentukan pada taraf nyata 5\%. Hasil penelitian menunjukkan bahwa; (1) Ekstrak biji buah pinang dapat mematikan ulat Crocidolomia pavonana F; (2) Ekstrak biji buah pinang mempunyai nilai $\mathrm{LC}_{50}$ sebesar $1.17 \%$ untuk ulat Crocidolomia pavonana F; (3) Semakin tinggi konsentrasi ekstrak biji buah pinang maka semakin cepat mematikan ulat Crocidolomia pavonana $\mathrm{F}$.
\end{abstract}

Kata kunci: Ekstrak biji buah pinang, nilai $\mathrm{LC}_{50}$, nilai $\mathrm{LT}_{50}$, ulat krop kubis

\section{PENDAHULUAN}

Ulat krop kubis (Crocidolomia pavonana F.) merupakan salah satu jenis hama yang menimbulkan masalah pada pertanian kubis, dikenal sebagai hama yang sangat rakus. Ulat Crocidolomia pavonana memakan daun-daun yang masih muda dan juga memakan daun yang agak tua kemudian menuju ke titik tumbuh, sehingga dapat merusak daun dan menurunkan kualitasnya. Kerusakan yang ditimbulkannya dapat menurunkan hasil sampai $100 \%$ (Trizelia, 2002).

Pengendalian hama ulat krop kubis yang banyak dilakukan yaitu menggunakan insektisida kimiawi sintetik karena dianggap sangat efektif dalam menekan populasi hama dan mudah dilakukan. Penggunaan insektisida yang tidak tepat waktu, dosis dan interval penyemprotannya dapat menimbulkan masalah baru yaitu semakin resistennya hama terhadap insektisida, timbulnya resurjensi hama, ledakan populasi hama dan pencemaran lingkungan (Herminanto, 1997).

Salah satu tanaman yang berpotensi sebagai pestisida nabati untuk mengendalikan hama adalah tanaman pinang. Pinang adalah tanaman sejenis palma yang tumbuh di daerah Pasifik, Afrika, dan Asia khususnya Indonesia. Bagian dari tanaman pinang yang paling banyak digunakan sebagai insektisida nabati yaitu biji pinang muda (Areca catechu L.) karena bahan aktif yang paling tinggi ditemukan pada buah pinang masih muda (Haditomo, 2010). Biji pinang (Areca catechu L.) mengandung bahan aktif arekolin sejenis alkaloid, yang dapat menyebabkan kelumpuhan dan terhentinya pernafasan serangga (Eri, dkk., 2013).

Berdasarkan hasil uraian latar belakang di atas, maka perlu dilakukan penelitian mengenai efikasi ekstrak biji pinang (Areca catechu L.) terhadap mortalitas ulat krop kubis (Crocidolomia pavonana F.) di laboratorium. Penelitian ini bertujuan untuk mengetahui toksisitas ekstrak biji pinang (Areca catechu L.) terhadap mortalitas ulat krop kubis (Crocidolomia pavonana).

\section{BAHAN DAN METODE}

Penelitian ini dilaksanakan di Laboratorium Bioteknologi, Fakultas Pertanian, Universitas Lampung, pada bulan September sampai dengan Desember 2016. Bahan-bahan yang digunakan dalam penelitian ini ulat krop kubis, biji buah pinang, daun brokoli, dan air. Alat yang akan digunakan dalam penelitian ini adalah alat tulis, paper towel, kain kasa, toples (diameter $5 \mathrm{~cm}$, tinggi 
$4 \mathrm{~cm}$ ), kertas label, timbangan elektrik, blender, kuas kecil, ember, kain penutup, saringan, pinset dan gelas ukur.

Uji pendahuluan dilakukan dengan konsentrasi 25\%, 5\% dan 0\% (kontrol). Pengujian ini dilakukan dengan cara memblender $1 \mathrm{~kg}$ biji buah pinang segar yang dicampur dengan 11 air, kemudian hasil blenderan didiamkan selama 1 hari, ekstrak yang didapat adalah ekstrak pekat $50 \%$.

Daun brokoli dicelupkan dalam ekstrak biji buah pinang sebagai perlakuan, kemudian larva Crocidolomia pavonana diberi pakan daun brokoli perlakuan tersebut sebagai uji pendahuluan. Larva yang digunakan adalah instar II (dua). Sebanyak 10 ekor larva diberi makan daun brokoli yang sudah dicelupkan ke dalam ekstrak biji buah pinang pada masing-masing konsentrasi.

Hasil uji pendahuluan ekstrak biji buah pinang menunjukkan bahwa konsentrasi yang memberikan mortalitas lebih dari $50 \%$ adalah ekstrak biji buah pinang pada konsentrasi $25 \%$ yaitu dengan mortalitas $92,8 \%$, sedangkan konsentrasi ekstrak biji buah pinang $5 \%$ hanya memberikan mortalitas $21,3 \%$. Dengan angka kematian ini data belum dapat dianalisis secara probit. Hasil uji pendahuluan ini digunakan untuk menentukan konsentrasi ekstrak biji buah pinang yang digunakan pada uji berikutnya.

Penyediaan pakan serangga uji. Tanaman yang digunakan sebagai pakan dalam perbanyakan serangga uji dan aplikasi pestisida nabati ekstrak biji buah pinang adalah tanaman brokoli. Budidaya tanaman brokoli dimulai pada bulan Februari 2016 di rumah kaca Fakultas Pertanian Universitas Lampung. Penanaman brokoli menggunakan polibag dengan menggunakan media tanam campuran tanah dan pupuk kandang (1:1).

Infestasi ulat krop kubis. Dalam penelitian ini dibutuhkan 150 ulat krop kubis Crocidolomia pavonana. Ulat krop kubis dikumpulkan dari lapangan dan dipelihara di laboratorium. Larva dikumpulkan dari pertanaman kubis milik petani. Larva yang telah dikumpulkan lalu dikembangbiakan di dalam stoples yang berisi daun brokoli sebagai pakanannya dan stoples ditutup menggunakan kain kasa. Setelah menjadi imago, Crocidolomia pavonana dipindahkan ke stoples lain yang sudah diberi kapas yang sudah diolesi madu $50 \%$. Imago tersebut dipelihara sampai menghasilkan telur hingga berubah menjadi larva. Pada saat mencapai larva instar II, selanjutnya larva instar II ini digunakan sebagai larva uji.

Pembuatan ekstrak biji buah pinang. Biji buah pinang segar ditimbang sebanyak $1 \mathrm{~kg}$, dicuci bersih kemudian dikeringkan. Setelah itu disiapkan air sebanyak 11 kemudian biji diblender dan dicampur dengan air.
Kemudian hasil blender dimasukkan di ember lalu ditutup dan dibiarkan selama 1 hari. Setelah itu ekstrak yang sudah didiamkan di saring (Bunaiyah, dkk., 2013). Larutan biji buah pinang yang diperoleh adalah ekstrak pekat $(50 \%)$.

Kemudian dilakukan pengenceran konsentrasi ekstrak biji buah pinang menggunakan rumus di bawah ini:

$$
\mathrm{V}_{1} \mathrm{M}_{1}=\mathrm{V}_{2} \mathrm{M}_{2}
$$

Keterangan:

$\mathrm{V}_{1}=$ Volume larutan mula-mula $(\mathrm{ml})$

$\mathrm{M}_{1}=$ Konsentrasi larutan mula-mula (\%)

$\mathrm{V}_{2}=$ Volume larutan akhir (ml)

$\mathrm{M}_{2}=$ Konsentrasi larutan akhir (\%)

Dengan pengenceran tersebut didapatkan sejumlah larutan ektrak biji buah pinang dengan beberapa konsentrasi, yaitu 30\%, 20\%, 10\%, 5\%, 1\%, 0,8\%, 0,6\%, $0,4 \%, 0,2$ dan $0 \%$ yang digunakan sebagai konsentrasi uji toksisitas lanjutan. Untuk membuat ekstrak dengan konsentrasi $30 \%\left(\mathrm{M}_{2}\right)$ yaitu sebanyak $60 \mathrm{ml}$ ekstrak pekat biji buah pinang (V1) dengan konsentrasi awal 50\% (M1) dimasukkan kedalam gelas ukur. Dengan menggunakan rumus tersebut maka akan diperoleh volume akhir (V2) sebesar $100 \mathrm{ml}$ sehingga air yang perlu ditambahkan sebagai bahan pengencer larutan yaitu sebesar $40 \mathrm{ml}(100 \mathrm{ml}-60 \mathrm{ml}=40 \mathrm{ml})$.

Aplikasi ekstrak biji buah pinang. Daun brokoli pakan dicetak bundar menggunakan alat yang terbuat dari pipa dengan diameter $2 \mathrm{~cm}$. Kemudian daun cetakan ini dipotong menjadi 4 bagian. Potongan daun brokoli dicelupkan ke dalam ekstrak biji buah pinang sesuai dengan konsentrasinya dan didiamkan selama 5 menit. Pakan tersebut dikeringkan di atas kertas tisu selama 5 menit. Pakan tersebut dimasukkan di dalam stoples aplikasi. Ke dalam stoples diletakkan sebanyak satu ekor larva Crocidolomia pavonana. Satu stoples perlakuan menggunakan satu ekor ulat dengan pakan $1 / 4$ dari daun yang sudah dicetak bundar. Pengamatan kematian dilakukan terhadap ulat krop setiap 24 jam setelah aplikasi. Pakan yang habis diganti dengan pakan yang baru tanpa diaplikasi ekstrak biji buah pinang.

Pengamatan. Peubah yang diamati pada penelitian ini meliputi mortalitas harian (\%) dengan menghitung jumlah ulat krop kubis yang mati sejak 1 hari setelah aplikasi (HSA) dan perubahan perilaku dan cacat fisik tubuh larva Crocidolomia pavonana.

Analisis Data. Data hasil penelitian akan diolah dan disajikan dalam bentuk tabel. Data dari uji daya racun tersebut dianalisis dengan analisis probit menggunakan 
Software SPSS version 23 for windows. Nilai toksisitas $\mathrm{LC}_{50}$ ekstrak biji buah pinang ditentukan pada taraf nyata $5 \%$.

Toksisitas ekstrak biji buah pinang terhadap ulat krop kubis. Hasil pengamatan toksisitas dari ekstrak biji buah pinang terhadap ulat krop kubis (Crocidolomia pavonana F.) menunjukkan bahwa ekstrak biji buah pinang bersifat toksik dan dapat menyebabkan mortalitas hama ulat krop. Kematian ulat krop kubis non kumulatif dapat dilihat pada Gambar 1, sedangkan kematian ulat krop kumulatif dapat dilihat pada Gambar 2. Gambar 1 menunjukkan bahwa setelah 7 hsa tidak ada lagi tambahan kematian ulat krop kubis. Dalam hal ini pada konsentrasi $30 \%$ semua ulat uji (15 ekor) sudah mati pada hari ke-3. Pada 7 hsa semua ulat uji yang hidup sudah menjadi pupa.

Gambar 2 menunjukkan bahwa perlakuan dengan konsentrasi $30 \%$ menyebabkan mortalitas yang paling
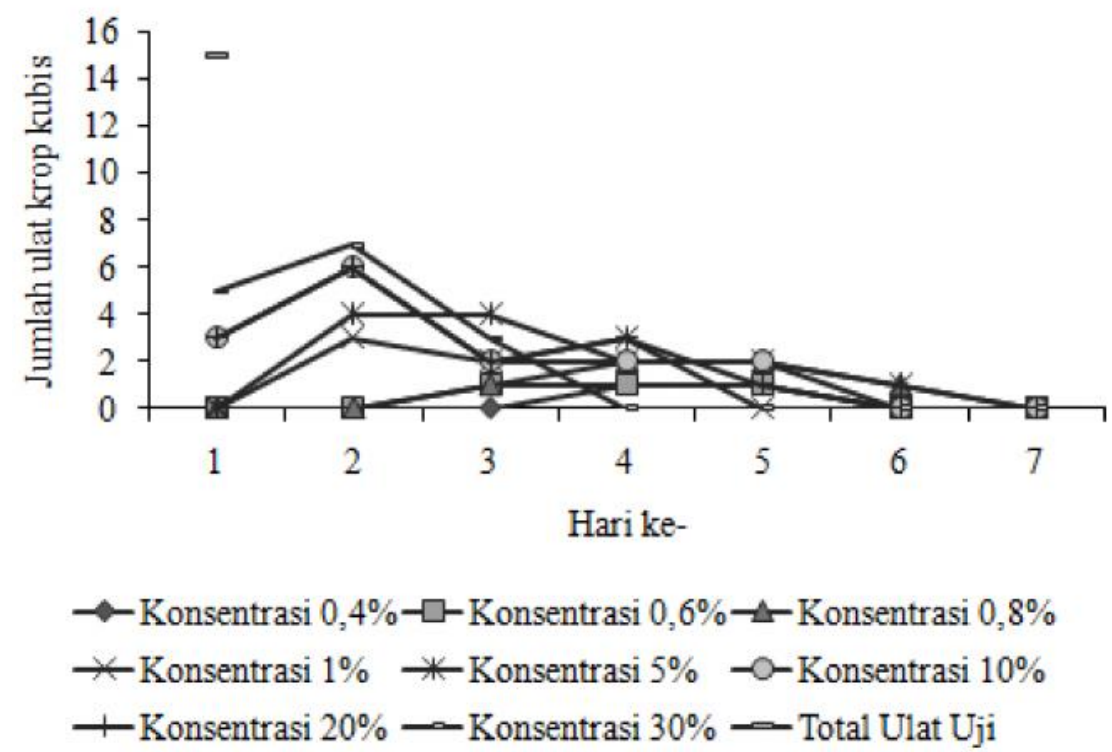

Gambar 1. Kurva mortalitas harian non kumulatif ulat krop kubis yang diperlakukan dengan ekstrak biji buah pinang.

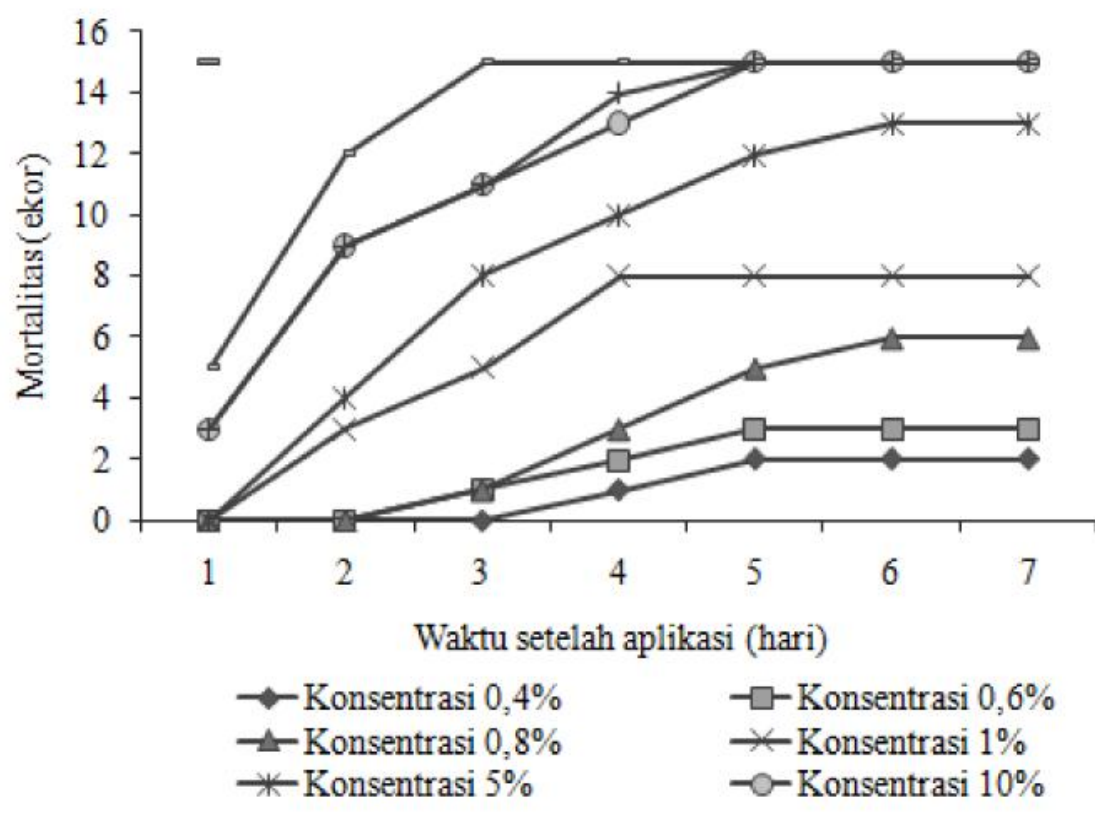

Gambar 2. Kurva mortalitas kumulatif ulat krop kubis yang diperlakukan dengan ekstrak biji buah pinang. 
cepat terhadap ulat krop yaitu 100\% (15 ekor) pada hari ke-3 setelah aplikasi. Mortalitas ulat krop kubis yang terendah atau lebih lama terjadi pada konsentrasi $0,4 \%$ total kematian ulat krop sampai hari terakhir pengamatan hanya 13,33\% (2 ekor). Pada konsentrasi 0,2\% dan 0\% (kontrol) tidak terjadi kematian ulat krop kubis sampai hari terakhir pengamatan.

Nilai $L_{50}$ hasil analisis probit ekstrak biji buah pinang terhadap ulat krop kubis. Konsenstrasi yang digunakan dalam penelitian ini adalah $0 \% ; 0,2 \%$; $0,4 \% ; 0,6 \% ; 0,8 \% ; 1 \% ; 5 \% ; 10 \% ; 20 \%$; dan 30\%. Pada konsentrasi terendah sampai konsentrasi tertinggi $(0,4$ $10 \%$ ) didapatkan persentase kematian ulat krop kubis sebesar 13,33\%; 20\%; 40\%; 53,33\%; 86,67\%; dan $100 \%$. Sedangkan pada konsentrasi $20 \%$ dan $30 \%$ didapatkan persentase kematian $100 \%$. Pada konsentrasi $0 \%$ (kontrol) dan 0,2\% tidak ada ulat krop kubis yang mati pada 7 hsa. Data hasil penelitian selanjutnya dianalisis probit menggunakan software SPSS v23 for windows untuk mendapatkan nilai $\mathrm{LC}_{50}$. Analisis probit menunjukkan bahwa konsentrasi ekstrak biji buah pinang kisaran 0,57 - 2,04\% memberikan efek toksik terhadap 50\% populasi ulat krop kubis dengan nilai $\mathrm{LC}_{50} 1,17 \%$ pada 6 hari setelah aplikasi (HSA). Tabel $\mathrm{LC}_{50}$ dapat dilihat pada Tabel 5 lampiran.

Nilai $L T_{50}$ hasil analisis probit ekstrak biji buah pinang terhadap ulat krop kubis. Hasil pengamatan terhadap ulat krop kubis dari pemberian berbagai konsentrasi ekstrak biji buah pinang setelah dianalisis secara probit menunjukkan adanya perbedaan waktu yang dibutuhkan untuk mematikan ulat krop yang diuji. Semakin tinggi konsentrasi ekstrak biji buah pinang semakin rendah nilai $\mathrm{LT}_{50}$. Hasil analisis probit terhadap ulat krop kubis terdapat pada Tabel 1. Tabel 1 menunjukkan bahwa perlakuan dengan konsentrasi $0,8 \%$ menunjukkan nilai $\mathrm{LT}_{50}$ pada 7,2 hari setelah aplikasi. Konsentrasi $20 \%$ menunjukan nilai $\mathrm{LT}_{50}$ pada
2,2 hari setelah aplikasi. Data di atas menunjukkan bahwa hasil analisis probit $\mathrm{LT}_{50}$ ekstrak biji buah pinang terhadap ulat krop kubis pada konsentrasi $20 \%$ paling cepat mematikan 50\% ulat krop kubis yaitu 2,2 hari setelah aplikasi.

Perubahan prilaku dan fisik ulat krop kubis. Berdasarkan hasil penelitian yang telah dilakukan, terlihat bahwa terjadi perubahan prilaku pada ulat krop setelah aplikasi ekstrak biji buah pinang. Gejala yang terjadi pada larva $C$. pavonana ditandai dengan perubahan perilaku yang memperlihatkan gerak semakin lambat sampai akhirnya tidak bergerak sama sekali. Nafsu makan larva juga menurun bahkan ada gejala tidak makan sama sekali. Larva berubah warna dari hijau menjadi krem kehijauan dan tubuhnya menjadi lembek. Larva $C$. pavonana pada perlakuan konsentrasi $0 \%$ (kontrol) dan $0,2 \%$ tidak ada yang mati, dan bergerak seperti biasanya sebagai larva yang sehat.

Toksisitas ekstrak biji buah pinang terhadap ulat krop kubis. Hasil penelitian menunjukkan bahwa ekstrak biji buah pinang bersifat toksik terhadap ulat krop kubis (Crocidolomia pavonana F.) dan dapat menyebabkan mortalitas. Hal ini sesuai dengan pendapat Isroj (2008) yang menyatakan bahwa perlakuan pestisida nabati ekstrak biji buah pinang mempunyai potensi sebagai racun kontak yang berspektrum luas, racun saraf dan menggunkan sistem metabolism, sehingga ulat yang memakan racun akan mati kelaparan karena tidak bisa melakukan aktifitas makan akibat kelumpuhan sistem saraf mulut.

Hasil penelitian menunjukkan bahwa persentase mortalitas meningkat seiring dengan peningkatan konsentrasi ekstrak biji buah pinang (Gambar 2). Menurut Natawigena (1993), proses kematian hama akan semakin cepat dengan peningkatan konsentrasi yang digunakan.

Tabel 1. Toksisitas ekstrak biji buah pinang terhadap ulat krop kubis*.

\begin{tabular}{cccc}
\hline \multirow{2}{*}{ Konsentrasi $(\%)$} & \multicolumn{3}{c}{ LT $_{50}$ (hari) } \\
\cline { 2 - 4 } & Dugaan & Batas bawah & Batas atas \\
\hline 0,8 & 7,2 & 5,0 & 12,9 \\
1 & 5,0 & 2,1 & 9,0 \\
5 & 3,1 & 1,8 & 4,2 \\
10 & 2,2 & 0,7 & 3,0 \\
20 & 2,2 & 0,9 & 2,8 \\
\hline
\end{tabular}

*) Hasil analisis probit dengan taraf nyata 5\% (SPSS version 23 for windows) 

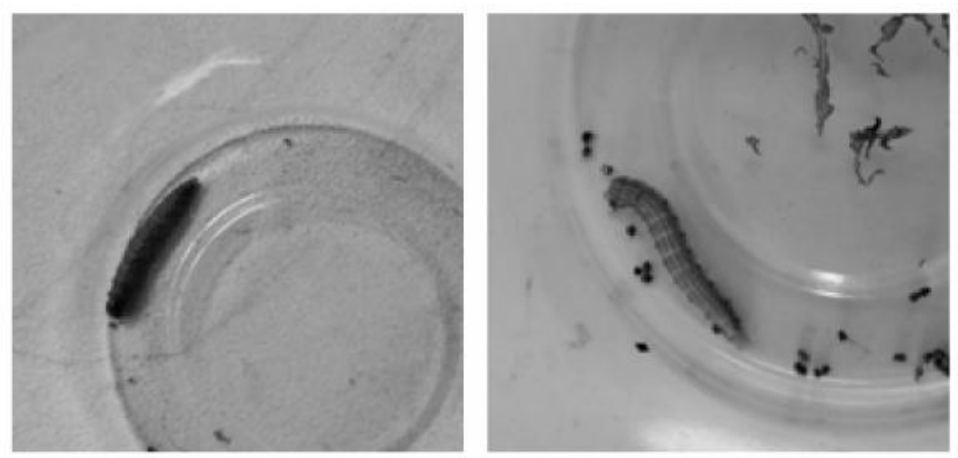

Gambar 3. Ulat krop kubis yang mati setelah aplikasi (a) dan ulat krop kubis yang sehat (b)

$\mathrm{LC}_{50}$ merupakan tolak ukur toksisitas suatu daya racun insektisida (Djojosumarjo, 2000). Hasil analisis probit dari data yang diperoleh menunjukan nilai $\mathrm{LC}_{50}$ ekstrak biji buah pinang terhadap larva ulat krop kubis yaitu $1,17 \%$. Dalam penelitian yang dilakukan Fitriani, dkk. (2013) ekstrak biji pinang juga dapat menyebabkan kematian terhadap kepik hijau (Nezara viridula L.). Hasil penelitian menunjukkan bahwa $\mathrm{LC}_{50}$ dari pemberian ekstrak biji pinang terhadap kepik ini yaitu konsentrasi $1,37 \%$. Hasil analisis probit $\mathrm{LT}_{50}$ menunjukkan bahwa perlakuan konsentrasi ekstrak biji buah pinang $20 \%$ dapat mematikan 50\% ulat krop kubis dalam kisaran waktu 2,2 hari setelah aplikasi (HSA), sedangkan pada konsentrasi $0,8 \%$ nilai $\mathrm{LT}_{50}$ didapatkan 7,2 HSA. Dalam penelitian Eri, dkk. (2013) diketahui bahwa ekstrak biji buah pinang juga dapat menyebabkan kematian pada ulat grayak (Spodoptera litura F.) dengan nilai $\mathrm{LT}_{50}$ sebesar 34,50 jam pada konsentrasi $40 \mathrm{~g} \mathrm{l}^{-1}$ air. Rusdy (1998) menyatakan bahwa semakin tinggi konsentrasi ekstrak biji buah pinang yang diujikan maka pengaruh yang ditimbulkan terhadap kematian serangga uji semakin tinggi.

Perubahan tingkah laku dan fisik ulat krop kubis (Crocidolomia pavonana F.). Berdasarkan penelitian yang telah dilakukan, terlihat bahwa terjadi perubahan tingkah laku pada ulat krop setelah aplikasi ekstrak biji buah pinang. Perubahan yang terjadi adalah pergerakan ulat krop yang mula-mula aktif menjadi sangat lambat. Kemampuan makan ulat krop yang mula-mula tinggi menjadi berkurang bahkan sampai tidak mau makan lagi.

Perubahan selanjutnya adalah pada hari ke-2 setelah aplikasi, perubahan tingkah laku dan fisik ulat krop kubis terjadi setelah diberi beberapa perlakuan konsentrasi ekstrak biji buah pinang. Perubahan fisik yang terjadi pada ulat krop adalah perubahan warna tubuh, dari warna hijau menjadi hijau kecoklatan (Gambar 3). Menurut Matsumura (1985) dalam Nursal, dkk. (1997) bahwa senyawa toksin yang terkandung dalam ekstrak biji buah pinang adalah senyawa arekolin yang dapat menyebabkan badan ulat menjadi kaku, sehingga aktivitas makan ulat terganggu dan mengakibatkan menurunya aktivitas metabolisme tubuh dan pencernaan.

\section{KESIMPULAN}

Berdasarkan hasil penelitian dapat disimpulkan bahwa ekstrak biji buah pinang dapat mematikan ulat Crocidolomia pavonana F. Semakin tinggi konsentrasi ekstrak biji buah pinang maka semakin cepat dan semakin banyak mematikan ulat Crocidolomia pavonana $\mathrm{F}$. Ekstrak biji buah pinang mempunyai nilai $\mathrm{LC}_{50}$ sebesar $1,17 \%$ untuk ulat Crocidolomia pavonana $\mathrm{F}$.

\section{DAFTAR PUSTAKA}

Bunaiyah, T. Wahyuni, dan U. P. Astuti. 2013. Petunjuk Teknis Pembuatan Pestisida Nabati. Balai Pengkajian Teknologi Pertanian (BPTP) Bengkulu. Bengkulu.

Djojosumarto, P. 2000. Teknik Aplikasi Pestisida Pertanian. Kanisius. Yogyakarta.

Eri, D. Salbiah dan H. Laoh. 2013. Uji beberapa konsentrasi biji pinang (Areca catechu) untuk mengendalikan hama ulat grayak (Spodoptera litura F.) pada tanaman sawi (Brassica juncea L.). Jurnal Faperta. Vol 1(2): 1-9.

Fitriani, M., H. Laoh. dan R. Rustam. 2014. Uji beberapa konsentrasi ekstrak biji pinang (Areca catechu L.) untuk mengendalikan kepik hijau (Nezara viridula L.) (Hemiptera: Pentatomidae) di laboratorium. Jurnal Online Mahasiswa 
Fakultas Pertanian Universitas Riau. Vol. 1(1): $1-11$.

Haditomo, I. 2010. Efek Larvasida Ekstrak Biji Pinang (Areca catechu) terhadap Aedes aegypti L. Skripsi. Fakultas Kedokteran Universitas Sebelas Maret Surakarta.

Herminanto. 1997. Pengamanan residu insektisida kimia pada bahan pangan sayuran brasika dari serangan hama Plutella xylostella L. melalui pengelolaan hama terpadu. Seminar Sehari Kependudukan, Pangan dan Kesehatan. Lembaga Penelitian Universitas Jenderal Soedirman. Purwokerto 12 April $1997.9 \mathrm{hlm}$.

Natawigena H. 1993. Dasar-dasar Perlindungan Tanaman. Penerbit Triganda Karya. Bandung.
Nursal, E., P. S. Sudharto, dan R. Desmier. 1997. Pengaruh konsentrasi ekstrak bahan pestisida nabati terhadap hama. Balai Penelitian Tanaman Obat. Bogor. Available online at http:// google.com, [1 januari 2014].

Rusdy, A., Hasnah, dan S. Hafsah. 1998. Uji Efektivitas Beberapa Dosis Biji Pinang (Areca catechu) untuk Mengendalikan Keong Mas Padi Sawah (Pomacea canaliculata). Laporan Penelitian. Universitas Syiah Kuala. Aceh. (Tidak dipublikasikan).

Trizelia. 2002. Pemanfaatan Bacillus thuringiensis untuk mengendalikan hama Plutella xylostella Linn. Available online at http;/rudyct, Tripod com/ sem 1-612/trizelia.html, [15 Desember 2016]. 